\title{
It takes time to see the menu from the body: an experiment on stable isotope composition in freshwater crayfishes
}

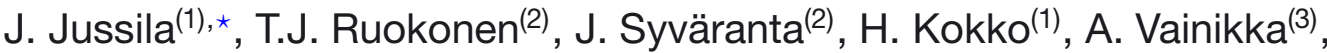 \\ J. Makkonen ${ }^{(1)}$, R. Kortet ${ }^{(3)}$ \\ Received May 22, 2015 \\ Revised August 19, 2015 \\ Accepted August 21, 2015
}

Key-words: nutrition, body composition, noble crayfish, signal crayfish, tissue anabolism

\section{ABSTRACT}

For many applications and ecological studies in which wild individuals are brought to laboratory it would be essential to know accurately how fast novel diet is reflected in composition of different tissues. To study the effects of two different diets on the stable isotope composition of freshwater crayfish muscle and hemolymph, we conducted a three month experiment on noble crayfish (Astacus astacus) and signal crayfish (Pacifastacus leniusculus) by feeding them sweet corn (Zea mays) or Baltic herring (Clupea harengus membras) as novel food. During the experiment, the crayfish were given $0.4 \mathrm{~g}$ of selected food daily and the amount consumed was recorded. The samples for the stable isotope analyses were taken at the commencement of the experiment (initial control) and three times (hemolymph) or twice (muscle tissue) during the experiment. We found that stable isotope changes can be similarly, and rather slowly, detected from muscle tissue and hemolymph under studied conditions. Hemolymph sampling, being non-lethal, can be recommended as a practical sampling method. Our results confirm earlier reports according to which diet changes reflect to crayfish isotope ratios slowly implying that isotope ratios indicate long-term diet.

\section{RÉSUMÉ}

II faut du temps pour voir la nourriture d'après le corps : une expérience sur la composition des isotopes stables chez des écrevisses

Mots-clés : nutrition, composition corporelle, écrevisse noble,
Pour de nombreuses applications et des études écologiques dans lesquelles des individus sauvages sont apportés au laboratoire, il serait essentiel de connaitre avec précision à quelle vitesse l'alimentation nouvelle se reflète dans la composition des différents tissus. Pour étudier les effets de deux régimes différents sur la composition en isotopes stables du muscle et de l'hémolymphe d'écrevisses, nous avons mené une expérience de trois mois sur l'écrevisse noble

(1) Department of Biology, Kuopio campus, the University of Eastern Finland, P.O. Box 1627, 70211 Kuopio, Suomi-Finland

(2) Department of Biological and Environmental Science, Section of Aquatic Sciences, The University of Jyväskylä, P.O. Box 35, 40014 Jyväskylä, Suomi-Finland

(3) Department of Biology, Joensuu campus, the University of Eastern Finland, P.O. Box 111, 80101 Joensuu, Suomi-Finland

* Corresponding author: japo.jussila@uef.fi 
écrevisse signal, (Astacus astacus) et l'écrevisse signal (Pacifastacus leniusculus) en les nourrissant anabolisme tissulaire

de maïs doux (Zea mays) ou de hareng de la Baltique (Clupea harengus membras) comme nouveaux aliments. Pendant l'expérience, les écrevisses ont reçu 0,4 g de nourriture sélectionnée par jour et la quantité consommée a été enregistrée. Les échantillons pour les analyses d'isotopes stables ont été pris au début de l'expérience (contrôle initial) et trois fois (hémolymphe) ou deux fois (tissus musculaires) pendant l'expérience. Nous avons trouvé que les changements d'isotopes stables peuvent être similaires, et plutôt lents, détectés à partir de tissu musculaire et de l'hémolymphe dans les conditions étudiées. L'échantillonnage de l'hémolymphe, étant non létal, peut être recommandé comme une méthode d'échantillonnage pratique. Nos résultats confirment des données antérieures selon lesquelles les changements de régime se reflètent lentement dans les rapports isotopiques des écrevisses, impliquant que les rapports isotopiques indiquent le régime alimentaire sur un long terme.

\section{INTRODUCTION}

Studies using freshwater crayfish under laboratory conditions, including nutritional (Fotedar, 1999; Cortés-Jacinto et al., 2003; López-López et al., 2005), infection (Gruber et al., 2014) and behavioural (Vainikka et al., 2011; Gruber et al., 2014) experiments, are typically based on fairly non-standardized experimental animals that have been obtained from wild or mixed farmed populations. However, the history of the used individuals, especially the nutritional status and life cycle phase, can affect many results considerably at least until the first molt, and in the worst case, more than the treatment of interest in itself (Jussila, 1997; D'Abramo et al., 1989, 1997). The variation in individuals' background complicates experimental design and requires long-term studies to nullify the background interference and to allow room for estimating the impact of the treatment. In case of the crayfish, this might require studies that cover several molt cycles. However, the lack of knowledge about the temporal dynamics of nutrition changes on body composition limits our capacity to plan experiments with appropriate time scales.

Experimental conditions in laboratories are normally simplified which per se can cause bias in comparison to natural conditions. Despite intensive research on crayfish nutrition (D'Abramo et al., 1997; Saoud et al., 2012) there is still lack of knowledge on the nutritional requirements of freshwater crayfish. In addition to limiting intensification of commercial freshwater crayfish culture, the lack of data on nutritional impacts on crayfish anabolism creates unnecessary challenges for experimental work. This is the case, for example, when different aspects of the crayfish plague (Aphanomyces astaci, Schikora) and its relationship with freshwater crayfishes (Jussila et al., 2014; Makkonen, 2013; Gruber et al., 2014) are studied under simplified laboratory conditions and for example nutritional stress might be interfering treatments. There are several physiological indicators of the crayfish condition (e.g. Jussila, 1997) but they are mostly indicative rather than precisely quantitative, dependent on the life cycle and molt cycle phase of the individual crayfish and thus applicable only to individuals in certain developmental stages.

Another active line of crayfish research potentially affected by the experimental and nutritional issues is the aquatic ecosystem ecology, particularly the studies focusing on the role of crayfishes in ecosystems through assessment of crayfish stable isotopes ratios. Stable isotope analysis (SIA) has been established in aquatic ecology to evaluate organisms' trophic position in the ecosystem as well as tracing their interactions within the ecosystem and with the other components of the food web (Peterson and Fry, 1987; Post, 2002; Grey, 2006; Layman et al., 2012). Furthermore, the flow of nutrients and energy within the ecosystems may be followed using stable isotope techniques (Hicks, 1997; Parkyn et al., 2001, Vander Zanden et al., 2005; Layman et al., 2007; Kankaala et al., 2010). Importantly, many changes in environment and food webs (e.g. changes in land use, introduction of new species, large scale fish removals) 
are reflected in stable isotope ratios (Peterson and Fry 1987; Vander Zanden et al., 1999; Syväranta et al., 2011). So far, SIA has been used mainly in ecological field studies, where it has been proven to be very useful.

The advantage of the SIA is that it provides a time-integrated indication of the diet, a dietary signature, which reflects long term changes compared for example to stomach content analysis (Grey, 2006). On the other hand, the relationship between diet and stable isotope ratio may not always be straightforward due to species and also individual level differences in metabolism (Suring and Wing, 2009; Layman et al., 2012).

The key in interpreting SIA results relies on understanding the isotopic routing and turnover rates, which dictate how fast and accurately the nutrition is reflected in tissues (Grey, 2006; del Rio et al., 2009). The turnover rates differ among tissue types and are likely speciesdependent, but also depend on many nutritional issues, such as the quantity and quality of food, which are directly reflected in growth and the rate of tissue synthesis (Hobson and Clark, 1992; del Rio et al., 2009). Species-specific experimental work on turnover rates and isotope fractionation from diet to tissue are required to enhance the robustness of stable isotope methods in studies of trophic ecology. While such work has already been conducted in several species representing wide taxonomic groups, including birds and fishes, studies using large aquatic invertebrates remain scarce.

The turnover rate may be relatively fast in crustaceans, presumably faster than growth rate alone would suggest (Frazer et al., 1997; Schmidt et al., 2003; Suring and Wing, 2009). Moreover, the isotope turnover rate could be complicated in crustaceans because of the discontinuous and irregular growth patterns that follow as a consequence of the molting cycle (Holdich, 2002) and due to them being poikilothermic animals with metabolism speeding up during the warm water season (Holdich, 2002). In addition, the turnover rates are complicated by differences between tissues and individuals of the same species (Layman et al., 2012), the tissue lipid content being one factor in biasing SIA results (Bodin et al., 2007).

SIA has increasingly been used in ecological studies focusing on crayfishes (e.g. Stenroth et al., 2005, Roth et al., 2006; Ruokonen et al., 2012; Ercoli et al., 2013; Jackson et al., 2014), which motivated this investigation on how these methods could be applied to specific laboratory conditions and diets. The main aims of our study were 1) to define, under experimental nutritional treatment, the temporal dynamics of the stable isotope ratios in two freshwater crayfishes, the noble crayfish (Astacus astacus, Linné) and the signal crayfish (Pacifastacus leniusculus, Dana), and 2) to assess the effect of controlled, single food type diet on the condition of crayfish. We were specifically interested how the wild background of crayfish would influence the individual dynamics in isotope ratio change with respect to food manipulation. The present work fills the gap in the detailed experimental data on the diet effects on freshwater stable isotope dynamics, and serves as crucial background information for the interpretation of previous and forthcoming ecological SIA work on crayfishes.

\section{MATERIALS AND METHODS}

\section{> CRAYFISH AND EXPERIMENTAL CONDITIONS}

Wild crayfish used in the experiments were obtained from a commercial crayfish trader (the signal crayfish ( $P$. leniusculus)) and from a commercial trapper (the noble crayfish (A. astacus)). The signal crayfish were of mixed wild origin from Central and Southern Finland and held in commercial communal holding tanks for 24 weeks before the experiments during which time they had been given fish and pelleted crayfish feed (Trappy crayfish bait) as food. The noble crayfish were trapped in Lake Rytky (coords. N 62 $51^{\prime} 18^{\prime \prime}$, E $27^{\circ} 25^{\prime} 25^{\prime \prime}$ ) and had been held in the University of Eastern Finland Fish Farm tanks over the previous winter, and been given frozen peas and frozen roach (Rutilus rutilus, Linné) ad libitum as food.

The crayfish of both species were divided into two groups (two treatment groups in both species, $N=9$ in each) and placed in individual small cages $(L \times W \times H: 15 \times 11 \times 15 \mathrm{~cm})$ in tanks $(L \times W \times H: 600 \times 350 \times 300 \mathrm{~mm})$ in water of $15 \mathrm{~cm}$ depth. The weight of the experimental 


\section{Table I}

Proximate content, $\delta^{13} \mathrm{C}$ and $\delta^{15} \mathrm{~N}$ stable isotope values and C:N ratio of the used feeds, sweet corn (Zea mays, Linné) and Baltic herring (Clupea harengus membras, Linné). Proximate content has been estimated per $100 \mathrm{~g}$.

\begin{tabular}{|l|c|c|}
\cline { 2 - 3 } \multicolumn{1}{c|}{} & Sweet corn & Baltic herring \\
\hline Energy & $510 \mathrm{~kJ}$ & $602 \mathrm{~kJ}$ \\
Protein & $4.3 \mathrm{~g}$ & $16.0 \mathrm{~g}$ \\
Carbohydrate & $20.0 \mathrm{~g}$ & $0.0 \mathrm{~g}$ \\
Fat & $2.3 \mathrm{~g}$ & $8.9 \mathrm{~g}$ \\
$\delta^{\mathbf{1 3}} \mathbf{C}$ & $-11.3 \pm 0.14$ & $-20.9 \pm 0.40$ \\
$\delta^{15} \mathbf{N}$ & $5.9 \pm 0.40$ & $12.5 \pm 0.04$ \\
C:N & $18.1 \pm 1.40$ & $3.6 \pm 0.26$ \\
\hline
\end{tabular}

crayfish was $18.2 \pm 2.5 \mathrm{~g}$ (noble crayfish, sweet corn group), $18.8 \pm 3.2 \mathrm{~g}$ (noble crayfish, Baltic herring group), $32.8 \pm 3.8 \mathrm{~g}$ (signal crayfish, sweet corn group) and $31.9 \pm 4.0$ (signal crayfish, Baltic herring group). The water was pumped from the nearby Lake Kallavesi and filtered with a $5 \mu \mathrm{m}$ absolute filter to remove disease agents including crayfish plague spores ( $A$. astaci) (Jussila, et al., 2011). The water was recirculated within each tank with an aquarium pump (Fluval 1plus) and half of the water was changed every seven days, when the tanks were also cleaned of all solid waste (siphoning of the food remains and the faeces). Molts, mortalities and feeding were recorded at cleaning events, and individual food consumption was also recorded daily. Water temperature, $\mathrm{pH}$ and dissolved oxygen saturation $\mathrm{DO}-\%$ was measured weekly.

Water temperature was $16.5 \pm 0.5^{\circ} \mathrm{C}\left(\min -\max 15.5-17.4^{\circ} \mathrm{C}\right), \mathrm{DO}-\%$ was $72 \pm 13(\min -\max$ $37.5-86 \%)$ and $\mathrm{pH} 6.7 \pm 0.3$ (min-max 6.3-7.1). Water DO-\% had two dramatic declines during the experiment due to pump failures, when the DO- $\%$ was between $35 \%$ and $50 \%$, otherwise the DO- $\%$ remained at level of $70 \%-80 \%$. Water temperature increased steadily as the experiment progressed, due to approaching summer and influence of environmental temperature on laboratory air.

\section{> FEEDS AND FEEDING}

We chose two novel food types that were clearly distinct in their isotope composition from each other (Table I) and from the food crayfish had been given during the laboratory acclimatization, in the wild or commercial holding. The $\mathrm{C}_{4}$ photosynthesis fractionates less against the heavier ${ }^{13} \mathrm{C}$ thereby creating elevated $\delta^{13} \mathrm{C}$ values in plant material using the $\mathrm{C}_{4}$ carbon fixation compared to the more typical $\mathrm{C}_{3}$ plants (Peterson and Fry, 1987). It is also well established that animals in marine food webs have elevated $\delta^{13} \mathrm{C}$ and $\delta^{15} \mathrm{~N}$ values compared to their freshwater counterparts (Peterson and Fry, 1987). Since the crayfish were fed using a combination of $\mathrm{C}_{3}$ plants (potatoes and carrots) during acclimation before the experiment, we chose $\mathrm{C}_{4}$ plant and animal feed that had elevated $\delta^{13} \mathrm{C}$ and $\delta^{15} \mathrm{~N}$. The feeds were commercial brand sweet corn (Zea mays, Linné) and frozen filleted Baltic herring (Clupea harengus membras, Linné). The crayfish were given either two corn seeds $(0.40 \mathrm{~g})$ or two pieces of Baltic herring $(0.45 \mathrm{~g})$ daily, at an average daily rate of $2.2 \%$ of body weight. The leftovers from previous feeding were removed before fresh food was added to the individual rearing cages. Food administration and consumption was recorded daily. The ingestion rate of food was expressed as food consumed in proportion to crayfish body mass (PTB) in order to enable comparisons of feeding ratio of differently sized crayfish.

\section{> SAMPLING AND ANALYSES}

Crayfish were sampled for hemolymph four times and for muscle tissue three times during the experiment. Sampling dates for the hemolymph were day 0 (20.2.2012, $N=9$ crayfish 
from both species), day 23 (16.3, all crayfish), day 49 (11.4, all crayfish) and day 93 (25.5, all crayfish) and for the muscle tissue were day 0 (20.2, $N=9$ crayfish from both species), day 49 (11.4, $N=4$ in all groups) and day $93(25.5, N=4$ or 5 in all groups). The initial hemolymph and muscle samples (day 0 ) were taken before the experiment started. During the experiment, crayfish were selected randomly for the muscle sampling, using the same random protocol for each treatment to maintain similar conditions among the caged crayfish.

The hemolymph for the stable isotope analyses was taken from the lateral side of the tail, just under the tail membrane. A total of $500 \mu \mathrm{L}$ was drawn, except for a few cases when only a smaller volume could be recovered. The hemolymph was transferred in a $2 \mathrm{~mL}$ Eppendorf tube, placed on ice, later centrifuged $(13000 \times$ for $10 \mathrm{~min})$ to separate the plasma. The plasma was then transferred into a fresh $2 \mathrm{~mL}$ Eppendorf tube and stored in $-20^{\circ} \mathrm{C}$ until preparation for SIA. Muscle sample (roughly $1 \mathrm{~g}$ ) was dissected from the tail muscle, transferred into an Eppendorf tube and kept in the freezer in $-20^{\circ} \mathrm{C}$ until preparation for SIA. The hepatopancreas and part of the muscle were then used for the condition index analyses as described in the next paragraph.

\section{$>$ CONDITION INDICES}

To estimate the hepatosomatic index, the crayfish were dissected immediately after removal from the experimental system. The whole hepatopancreas was removed, placed in a tared foil cup and weighed. Whole hepatopancreases were then dried at $80^{\circ} \mathrm{C}$ for $24 \mathrm{~h}$ and reweighed. Results were expressed as hepatopancreas moisture content (Eq. (1)) (Jussila, 1997; Jussila and Mannonen, 1997). The muscle moisture was estimated after similar dissection process (Eq. (2)), except that the muscle sample for the isotope analyses was taken prior to the tissue processing.

$$
\mathrm{HM} \%=(\mathrm{Wwh}-\mathrm{Wdh}) \times 100 / \mathrm{Wwh}
$$

where: $W w h=$ weight of wet hepatopancreas $(g) ; W d h=$ weight of dry hepatopancreas $(g)$

$$
\mathrm{MM} \%=(\mathrm{Mwm}-\mathrm{Mdm}) \times 100 / \mathrm{Mwm}
$$

where: Mwm = weight of wet muscle sample (g); Mdm = weight of dry muscle sample (g).

\section{> STABLE ISOTOPE ANALYSIS}

All samples for isotope analysis were freeze dried to constant weight using Christ Alpha 1-4 LD Plus (Martin Christ Gefriertrocknungsanlagen $\mathrm{GmbH}$, Osterode am Harz, Germany) and ground to a homogenous fine powder. Samples were then accurately weighed $(0.5-0.7 \mathrm{mg})$ into small tin cups and encapsulated. Analysis of carbon and nitrogen isotope ratios were done at the University of Jyväskylä, using a FlashEA 1112 elemental analyzer coupled to a Thermo Finnigan DELTAplus Advantage mass spectrometer (Thermo Electron Corporation, Waltham, MA, USA.). Dried and homogenised pike (Esox lucius) white muscle tissue was used as an internal working standard and one replicate sample was run repeatedly after every six samples in each sequence. Stable isotope ratios are expressed as parts per thousand (\%o) delta values $\left(\delta^{13} \mathrm{C}\right.$ or $\left.\delta^{15} \mathrm{~N}\right)$ referred to the international standards for carbon (PeeDee Belemnite) and nitrogen (atmospheric nitrogen) (Peterson and Fry, 1987). Standard deviations within reference samples in each sequence were less than $0.14 \%$ for carbon and $0.18 \%$ o for nitrogen.

\section{> ETHICAL CONSIDERATIONS}

All experiments followed the currently existing national and international guidelines for the use of animals in experiments and comply with the current legislation of Finland. Special care was taken to prevent the spread of possible pathogens into nature. 


\section{Table II}

Food intake during the experiment. The amount of food ingested indicated as a proportion of the body mass (PBM) and estimated per sampled group in each of the experimental sampling groups as mean \pm $S D$. The proportion of administered food consumed (PAFC) expressed as the mean percentage per each of the experimental sampling group. Different superscript numbers indicate statistically significant difference with each column. Different superscript letters indicate statistically significant difference between sampling times for each individual variable within the experimental group.

\begin{tabular}{|l|c|c|c|c|}
\hline \multirow{2}{*}{ Group } & \multicolumn{2}{|c|}{ PBM } & \multicolumn{2}{|c|}{ PAFC, \% } \\
\cline { 2 - 5 } & $I(1 \mathrm{mo})$ & $11(3 \mathrm{mo})$ & $1(1 \mathrm{mo})$ & $11(3 \mathrm{mo})$ \\
\hline Noble crayfish - sweet corn & ${ }^{1} 0.87 \pm 0.15^{\mathrm{a}}$ & ${ }^{1} 1.42 \pm 0.11^{\mathrm{b}}$ & ${ }^{1} 95 \pm 9^{\mathrm{a}}$ & ${ }^{1} 91 \pm 6^{\mathrm{a}}$ \\
Noble crayfish - Baltic herring & ${ }^{2} 0.61 \pm 0.04^{\mathrm{a}}$ & ${ }^{2} 0.92 \pm 0.17^{\mathrm{b}}$ & ${ }^{2} 61 \pm 4^{\mathrm{a}}$ & ${ }^{2} 65 \pm 13^{\mathrm{a}}$ \\
Signal crayfish - sweet corn & ${ }^{2} 0.58 \pm 0.05^{\mathrm{a}}$ & ${ }^{2,3} 0.74 \pm 0.19^{\mathrm{a}}$ & ${ }^{1} 97 \pm 0,1^{\mathrm{a}}$ & ${ }^{1} 97 \pm 2^{\mathrm{a}}$ \\
Signal crayfish - Baltic herring & ${ }^{2} 0.48 \pm 0.08^{\mathrm{a}}$ & ${ }^{3} 0.62 \pm 0.12^{\mathrm{a}}$ & ${ }^{1} 88 \pm 8^{\mathrm{a}}$ & ${ }^{2} 67 \pm 22^{\mathrm{b}}$ \\
\hline
\end{tabular}

\section{> STATISTICS}

Differences between crayfish muscle and hemolymph $\delta^{13} \mathrm{C}$ or $\delta^{15} \mathrm{~N}$ values were tested using paired samples $t$-tests, while the differences in the rate of isotope change between crayfish species and among treatment groups were tested using ANOVA (for muscle $\delta^{13} \mathrm{C}$ and $\delta^{15} \mathrm{~N}$ ) and repeated measures ANOVA (for hemolymph $\delta^{13} \mathrm{C}$ and $\delta^{15} \mathrm{~N}$ ). Differences in variances of $\delta^{13} \mathrm{C}$ or $\delta^{15} \mathrm{~N}$ values between crayfish species were tested using Levene's test at the beginning and at the end of the experiment. T-tests (large sample sizes) or Mann-Whitney U-test with the $p<0.05$ as the criteria for the statistical difference were used to compare food intake and crayfish condition indices. The molting rate differences were tested using Kaplan-Meier (Log-Rank) test. The statistical package utilised was SPSS v19.0.0.1.

\section{RESULTS}

\section{> GENERAL OBSERVATIONS}

During the experiment, two crayfish died: one noble crayfish in the Baltic herring diet group (day 16) and one signal crayfish in sweet corn diet group (day 72). We did not observe signs of repeated hemolymph sampling stress, similarly to what has also been observed before, for example by Gruber et al. (2014). There were few molts among experimental crayfish, with one crayfish molting in every group except for the signal crayfish Baltic herring group, in which two crayfish molted. The molting rate did not differ among treatments (Kaplan-Meier, Log-Rank, $p>0.05)$.

\section{> FOOD INTAKE AND CONDITION INDICES}

Feed consumption, expressed as proportion of body mass (PBM), varied between the diet groups and species (Table II) so that sweet corn consumption was highest among the noble crayfish (ANOVA, LSD Post Hoc test, $p<0.05$ ). In both species, sweet corn was favored over Baltic herring in both PBM and PAFC consumption estimates (ANOVA, LSD Post Hoc test, $p<0.05$ ). The proportion of administered food consumed (PAFC) was higher in the first sampling compared to the second one in all experimental groups in both species $(t-$ test, $p<0.05)$, except for the noble crayfish that had been fed using Baltic herring. The consumption rate (PBM) was higher in the first sampling (t-test, $p<0.05)$ only in the noble crayfish groups.

Initially, the hepatopancreas moisture index (HM\%) was statistically significantly higher in noble crayfish compared to signal crayfish (Table III). The hepatopancreas moisture content declined significantly in both noble crayfish groups ( $t$-test, $p<0.05$ ). The decline in hepatopancreas moisture content was larger in the Baltic herring fed group compared to the 


\section{Table III}

The hepatopancreas moisture (HM\%) and muscle moisture (MM\%) condition indices, expressed per experimental group as mean $\pm S D$. Different superscripts are indicating statistically significant difference with each treatment group's initial and final sampling in $\mathrm{HM} \%$ and $\mathrm{MM} \%$.

\begin{tabular}{|c|c|c|c|}
\hline & Sweet corn & HM & $\overline{M M}$ \\
\hline \multirow{5}{*}{ Noble crayfish } & Initial sample & $80.5 \pm 4.3^{a}$ & $83.0 \pm 1.3^{a}$ \\
\hline & Final sample & $52.0 \pm 11.1^{\mathrm{b}}$ & $80.3 \pm 1.4^{b}$ \\
\hline & Baltic herring & & \\
\hline & Initial sample & $80.5 \pm 4.3^{a}$ & $83.0 \pm 1.3^{a}$ \\
\hline & Final sample & $37.9 \pm 21.2^{b}$ & $77.8 \pm 0.7^{b}$ \\
\hline \multirow{6}{*}{ Signal crayfish } & Sweet corn & & \\
\hline & Initial sample & $59.0 \pm 17.9^{a}$ & $80.0 \pm 0.8^{a}$ \\
\hline & Final sample & $51.8 \pm 16.5^{a}$ & $79.4 \pm 2.2^{\mathrm{a}}$ \\
\hline & Baltic herring & & \\
\hline & Initial sample & $59.0 \pm 17.9^{a}$ & $80.0 \pm 0.8^{a}$ \\
\hline & Final sample & $43.0 \pm 13.5^{a}$ & $79.2 \pm 1.2^{a}$ \\
\hline
\end{tabular}

sweet corn fed group, but the difference was not statistically significant. There was considerable individual variation in hepatopancreas moisture content in the signal crayfish, both initially and at the end of the experiment. There was a slight, but not significant, declining trend in hepatopancreas moisture in both signal crayfish groups. In the noble crayfish, similar variation could be observed at the end of the experiment. We did not observe any differences in initial muscle moisture (MM\%) content between the two species and observed only a slight drop in the muscle moisture content during the study.

\section{$>$ STABLE ISOTOPES}

Both $\delta^{13} \mathrm{C}$ and $\delta^{15} \mathrm{~N}$ values were more variable in the signal crayfish than in the noble crayfish at the start of the experiment (Figure 1). The variance around mean $\delta^{13} \mathrm{C}$ and $\delta^{15} \mathrm{~N}$ values in the noble crayfish was less than 0.65 for both isotopes and in both muscle and hemolymph samples, while the variances in $\delta^{13} \mathrm{C}$ and $\delta^{15} \mathrm{~N}$ values of the signal crayfish were significantly higher at 2.5-4.3 (Levene's test all $p<0.001$ ). These interspecific differences in variances remained throughout the experiment although the difference was less evident at the end of the experiment due to increasing variance in the noble crayfish isotope values to $0.3-1.7$ in muscle and $0.4-1.9$ in hemolymph compared to $<0.65$ at the start. Similarly to the start, the variances in the signal crayfish isotope values were nevertheless higher for both isotopes (2.8-6.2 in muscle and 0.8-4.4 in hemolyph, all Levene's $p<0.01)$. Muscle had consistently higher mean $\delta^{13} \mathrm{C}$ and $\delta^{15} \mathrm{~N}$ values than hemolymph in both species. In the noble crayfish, muscle $\delta^{13} \mathrm{C}$ values were $1.1 \pm 0.3 \%$ ond $\delta^{15} \mathrm{~N}$ values $2.5 \pm 0.7 \%$ o higher (paired sample $t$-test: $\left.t_{8}=11.49, p<0.001 ; t_{8}=10.08, p<0.001\right)$ than in hemolymph, and similarly in the signal crayfish the values in muscle were $1.2 \pm 0.6 \%$ and $2.2 \pm 0.5 \%$ o higher than in hemolymph $\left(t_{8}=6.4, p<0.001 ; t_{8}=14.2, p<0.001\right)$.

\section{$>$ HEMOLYMPH}

The rate of isotope change in hemolymph $\delta^{13} \mathrm{C}$ values was slow throughout the 93 day experiment for both species and in both diet groups (Figure 2). Nevertheless, we observed a significant increase in $\delta^{13} \mathrm{C}$ values for both species under corn diet $\left(F_{1,3}=5.9, p=0.016\right.$ for the noble crayfish and $F_{1,3}=15.5, p=0.001$ for the signal crayfish) and similarly a significant difference between the two species in the rate of $\delta^{13} \mathrm{C}$ change, as the noble crayfish $\delta^{13} \mathrm{C}$ values elevated quicker than those of the signal crayfish $\left(F_{1,6}=22.9, p=0.003\right)$. No differences, however, were observed in $\delta^{13} \mathrm{C}$ values under the Baltic herring diet. $\delta^{15} \mathrm{~N}$ values similarly increased slowly during the entire experiment, particularly under the Baltic herring diet, without 


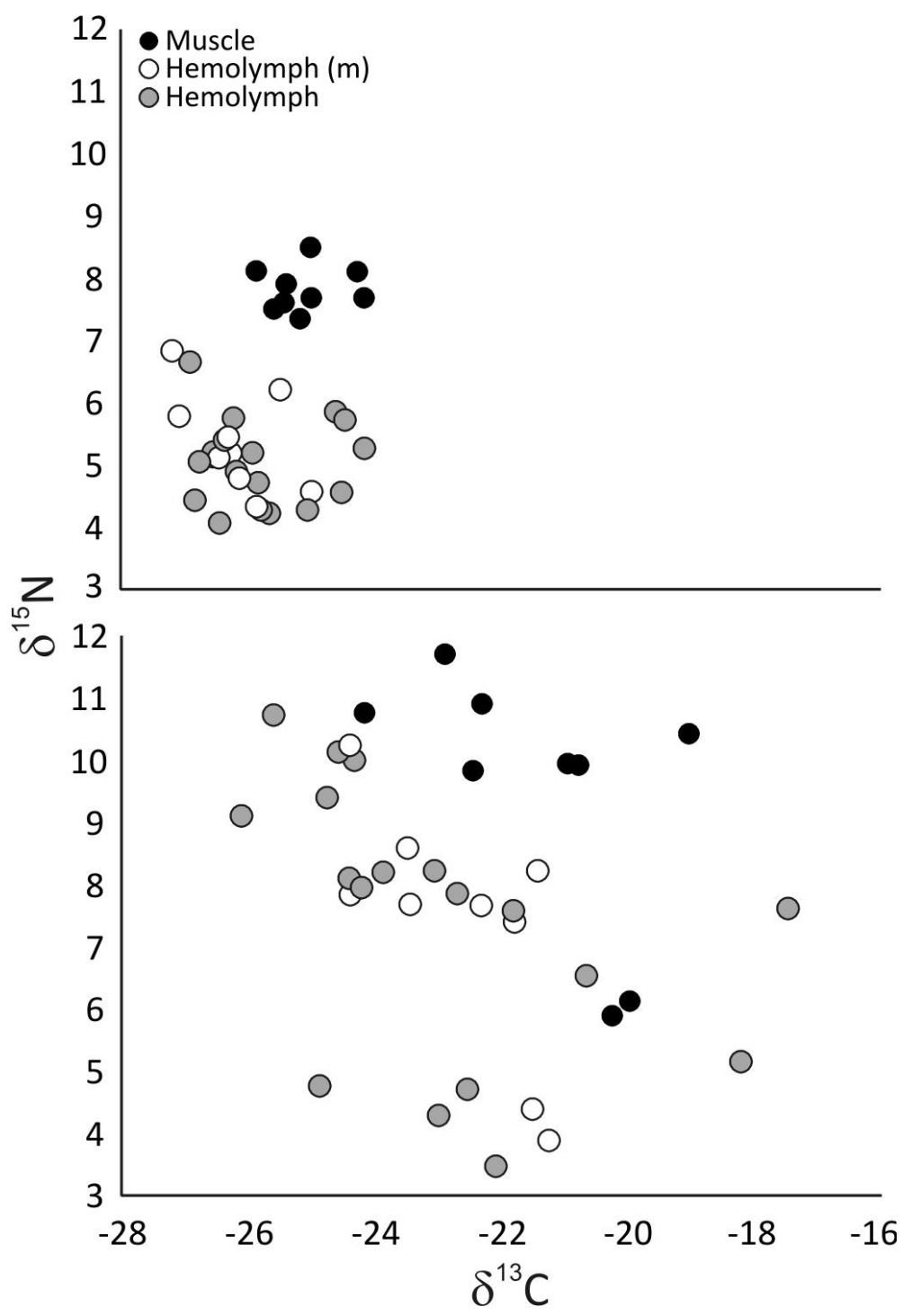

\section{Figure 1}

Carbon and nitrogen stable isotope values in hemolymph and muscle tissue of noble crayfish (upper panel) and signal crayfish (lower panel). Samples were taken at the beginning of the experiment when the crayfish had been administered variable diets of pelleted feed, fish, carrots and peas and before introducing novel diets (herring and corn). Muscle samples were taken from 9 additional individuals which were not used for the experiment while hemolymph samples were taken from these same 9 individuals $(=h e m o l y m p h(m))$ and all individuals $(n=18)$ used for the experiment.

clear signs of levelling off (Figure 2). The $\delta^{15} \mathrm{~N}$ values in the noble crayfish elevated significantly under the Baltic herring diet $\left(F_{1,3}=6.9, p=0.010\right)$ but no statistical significance was observed in the signal crayfish. Therefore the two species differed statistically significantly in the rate of $\delta^{15} \mathrm{~N}$ change under herring diet $\left(F_{1,6}=6.2, p=0.047\right)$.

In general, however, $\delta^{13} \mathrm{C}$ and $\delta^{15} \mathrm{~N}$ values in both crayfish species and both feeding groups never reached the expected levels during the experiment. The $\delta^{13} \mathrm{C}$ values (mean $\pm \mathrm{SD}$ ) in sweet corn fed noble crayfish increased from $-25.9 \pm 0.7 \%$ o to $-21.8 \pm 1.3 \%$ o and in the signal crayfish from $-22.8 \pm 2.2 \%$ o to $-21.5 \pm 0.9 \%$, while the $\delta^{13} \mathrm{C}$ value of sweet corn was $-11.3 \pm 0.1 \%$. The $\delta^{15} \mathrm{~N}$ values of crayfish on sweet corn diet remained similarly lower than their diet in Baltic herring feeding (the noble crayfish from $5.0 \pm 0.8 \%$ o to $10.2 \pm 0.8 \%$ o and the signal crayfish from $6.9 \pm 2.5 \%$ o to $9.5 \pm 1.5 \%$ o), where the diet had a $\delta^{15} \mathrm{~N}$ value of $12.5 \pm 0.0 \%$. 

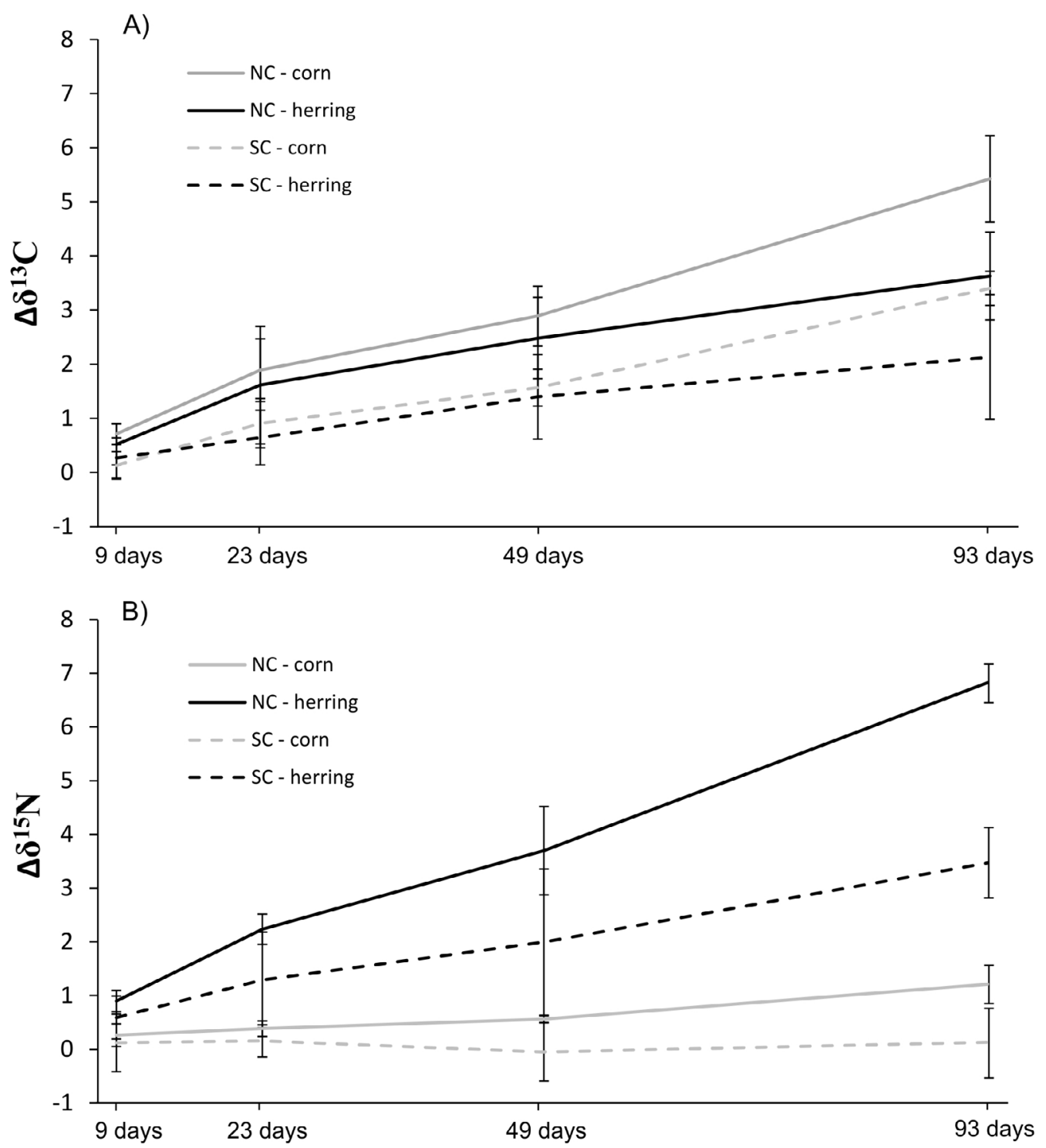

\section{Figure 2}

Changes in mean $( \pm S D) \delta^{13} C$ and $\delta^{15} \mathrm{~N}$ values in hemolymph of noble crayfish (NC) and signal crayfish (SC) fed Sweet corn and Baltic herring. $\Delta$-values refer to the difference in $\delta^{13} \mathrm{C}$ and $\delta^{15} \mathrm{~N} \%$ values in hemolymph between each consecutive sampling day. Lines are extrapolated between the measurement occasions.

\section{> MUSCLE TISSUE}

Muscle tissue $\delta^{13} \mathrm{C}$ values in the noble crayfish increased significantly under both sweet corn and Baltic herring diets $\left(F_{2,17}=46.7, p<0.001\right.$ for sweet corn and $F_{2,16}=28.3, p<0.001$ for Baltic herring, Figure 3). In both treatments, the $\delta^{13} \mathrm{C}$ values of muscle tissue at the start of the experiment differed significantly from those after 49 and 93 days of feeding on new diet, but values observed at 49 and 93 days were not different from each other. A decreasing trend was observed in $\delta^{15} \mathrm{~N}$ values of the noble crayfish under sweet corn diet (Figure 3), while Baltic herring diet resulted in significantly elevated $\delta^{15} \mathrm{~N}$ values $\left(F_{2,16}=46,9, p<0.001\right)$. Similarly to $\delta^{13} \mathrm{C}$ under sweet corn diet, the $\delta^{15} \mathrm{~N}$ values at the start of the experiment differed significantly from those of day 49 and 93 under the Baltic herring diet while values at day 49 and 93 were not different. Only $\delta^{13} \mathrm{C}$ values under sweet corn diet resulted in significant elevation in the signal crayfish $\left(F_{2,16}=7.5, p=0.006\right)$, reflecting the highly variable isotope values of the signal crayfish at the beginning of the experiment. 
A)

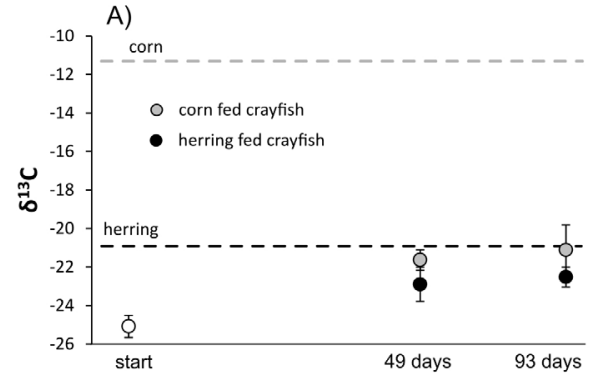

C)

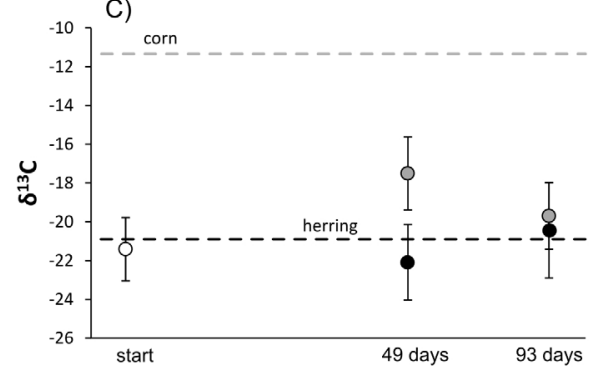

B)

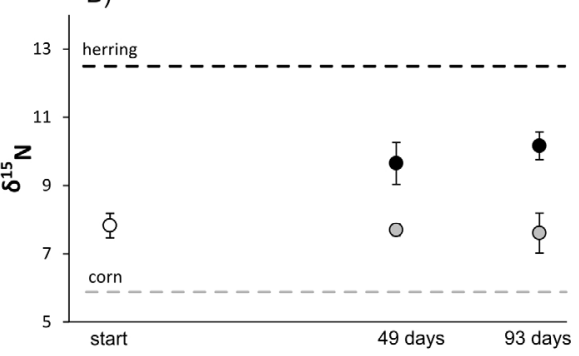

D)

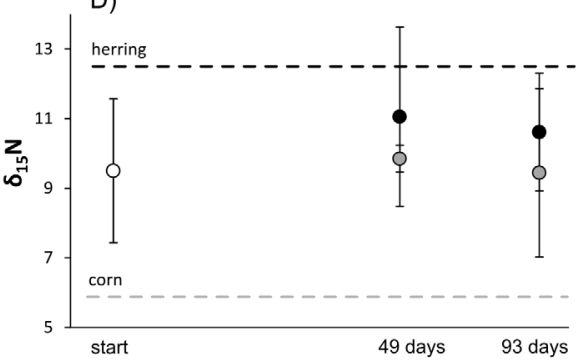

Figure 3

Mean $( \pm S D) \delta^{13} C(A)$ and $\delta^{15} N(B)$ in the noble crayfish muscle, and in $\delta^{13} \mathrm{C}(C)$ and $\delta^{15} \mathrm{~N}(D)$ in the signal crayfish muscle fed sweet corn and Baltic herring. White circles denotes mean $( \pm S D) \delta^{13} C$ and $\delta^{15} \mathrm{~N}$ ratios at the beginning of the experiment. Dashed lines indicate $\delta^{13} \mathrm{C}$ and $\delta^{15} \mathrm{~N}$ values of sweet corn and Baltic herring.

\section{DISCUSSION}

Here, we show that different food sources with distinct characteristics in their stable isotope rations are reflected in the stable isotope content of both hemolymph and muscle tissue in crayfish during a reasonable, three months long, time span. There were distinct changes in both $\delta^{13} \mathrm{C}$ and $\delta^{15} \mathrm{~N}$, but we did not observe stabilization of the values within the $93 \mathrm{~d}$ experiment. The effects of nutritionally inadequate feeding and even starvation, an outcome of the laboratory conditions, could be reflected in these data as suggested by the condition indices. The used feeds might not have provided enough resources for both basic maintenance and growth, influencing the slow turnover of tissues.

In general, both $\delta^{13} \mathrm{C}$ and $\delta^{15} \mathrm{~N}$ values were lower in hemolymph compared to muscle tissue in both crayfish species $\left(\delta^{13} \mathrm{C}\right.$ by $\sim 1 \%$ and $\delta^{15} \mathrm{~N}$ by $\sim 2.5 \%$ ). This likely reflects the differences in tissue dependent isotope fractionation and routing between muscle tissue and hemolymph (Gannes et al., 1997). However, the isotope turnover was faster in hemolymph and the differences between sample tissues were smaller towards the end of the experiment suggesting that also muscle isotope ratios will fully reflect the current diet after ca. 100 days. Based on our experience, sample taken from hemolymph, sampling being simple to perform and nonlethal, would be better suited for experimental purposes than the muscle samples that require killing of the animal.

The administered diet, even though it should be clearly reflected in isotope ratios, does not necessarily totally alter the species specific ratios, as was observed in this study. Previously, the turnover rates of $\delta^{15} \mathrm{~N}$ and $\delta^{13} \mathrm{C}$ in large crustaceans, especially freshwater crayfish, have been scarcely studied, while there are reports indicating that in yabbie (Cherax destructor) about 80 days is sufficient for the $\delta^{15} \mathrm{~N}$ to reach equilibrium with novel food (Carolan et al., 2012). However, the length of the study by Carolan et al. (2012) was not sufficient enough to establish an equilibrium in $\delta^{13} \mathrm{C}$. The turnover rate has been reported to be an order of magnitude greater than dilution by growth for both $\delta^{15} \mathrm{~N}$ and $\delta^{13} \mathrm{C}$ in crustacean tissues (Suring and Wing, 2009; Carolan et al., 2012). It has been suggested that if the diet is insufficient, crustaceans may, in the state of starvation, fractionate stable isotopes, such as $\delta^{15} \mathrm{~N}$, differently, 
due to utilising their own tissues to substitute nutritional deficiencies (Fantle et al., 1999). This could be the situation occurring during long term laboratory studies, where animals are being held in simplified conditions and nutrition. The case of $\delta^{13} \mathrm{C}$ turnover and fractioning could be different, possibly due to selective feeding (Fantle et al., 1999).

One of the few earlier studies on the subject is a 205 day study on the red rock lobster (Jasus edwardsii, Hutton), where slow but significant turnover was observed for $\delta^{13} \mathrm{C}$ and $\delta^{15} \mathrm{~N}$ both in hemolymph and muscle (Suring and Wing, 2009). The half-lives for these tissues were similar and estimated at 117 and 147 days, respectively, while significant differences were found in the isotope fractionation between hemolymph and muscle. Fractionation of $\delta^{13} \mathrm{C}$ and $\delta^{15} \mathrm{~N}$ values in hemolymph was $-0.3 \%$ and $1.1 \%$, while in muscle $0.8 \%$ and $3.3 \%$, respectively (Suring and Wing, 2009). While only few experimental studies have been done with similar species, the reported fractionation values are highly variable. For example, Yokoyama et al. (2005) reported fractionation in the ghost shrimps (Nihonotrypaea japonica, Ortmann and $N$. harmandi, Bouvier) to be $2.0-2.2 \%$ for $\delta^{13} \mathrm{C}$ and $3.6-4.0 \%$ for $\delta^{15} \mathrm{~N}$, while Rudnick and Resh (2005) reported similarly variable values (1.9-2.0\% and $1.0-6.0 \%$ o for $\delta^{13} \mathrm{C}$ and $\delta^{15} \mathrm{~N}$ ) for the Chinese mitten crab (Eriocheir sinensis, Milne-Edwards) and the red swamp crayfish (Procambarus clarkii, Girard).

The flexible usage, especially in the case of starvation, of both the available nutrition and own tissues through catabolism for basic maintenance (Gu et al., 1996; D'Abramo et al., 1997; Jones and Obst, 2000), complicates the stable isotope changes and composition. Utilisation of the nutrition, and thus stable isotope patterns could be complicated in crayfish as a possible reflection of their periodic tissue growth dynamics (e.g., Parkyn et al., 2001; Rudnick and Resh, 2005; Stenroth et al., 2006). It is recommended, on the other hand, that experiments studying effects of nutrition should be long enough, and cover at least two molts, to ensure that the effects of the treatments can be seen in tissue composition (e.g., D'Abramo et al., 1997). Normally, the first molt during the experiment is based on the pre-experiment history of the crayfish, i.e. nutritional intake in wild or in the holding tanks. The complexity of the crustacean tissue growth, as there were only a few molts during the experiment, could have compromised stable isotope dynamics in the present study, too.

In our study, crayfish accepted sweet corn more willingly than Baltic herring and the trend was stronger in the signal crayfish. Previously, it has been reported that high lipid content in food results in poor appetite and growth (Church and Pond, 1982; Davis and Robinson, 1986). It has also been observed that feeds with high fat content are initially preferred but later ignored, causing crayfish even to fast (our own observation). This might be due to high fat content in the feed accumulating in the digestive tissue, hepatopancreas, which might then be indicating satiation. If other essential nutrients are missing, the individual crayfish might actually be in the stage of starvation and, for example, incapable of molting. The unbalanced feed normally given under laboratory conditions might thus affect crayfish, and wider crustacean, condition and partially compromise simplified studies (Hazlett et al., 1975; Sánchez-Paz et al., 2006), although this effect is bound to influence all experimental groups similarly.

Our results showed larger initial individual variation in the signal crayfish in $\delta^{15} \mathrm{~N}$ and $\delta^{13} \mathrm{C}$ stable isotope ratios compared to that of the noble crayfish, and variation remained higher in the signal crayfish throughout the experiment. These results clearly indicate that by giving simple, nutritionally insufficient, food it is not possible to remove the effects of previous nutrition in short term experiments. Observed higher variation in stable isotope ratios in the signal crayfish could indicate that they may demonstrate a higher degree of individual specialization in feeding compared to the noble crayfish. This view is also supported by findings of Olsson et al. (2009) and Ercoli et al. (2014) both of whom showed that the signal crayfish used a wider range of resources (i.e. habitats and food sources) at the species level in natural populations compared to the noble crayfish. However, further long-term feeding experiments with several food sources are needed to reliably study individual differences with respect to crayfish species, as the origins of the noble and the signal crayfish were not standardized in our study. 
The signal crayfish had lower food intake levels than the noble crayfish throughout the study, as was indicated in the PBM estimates. This is partially caused by the slightly higher average weight of the signal crayfish compared to the noble crayfish in this study, as we administered equal amounts of feed to every individual crayfish. The actual proportion of administered food consumed (PAFC) was statistically slightly higher for the signal crayfish groups indicating that the given food was more readily accepted by signal crayfish. This might be due to the more aggressive nature of signal crayfish in comparision to the noble crayfish, often outcompeting the noble crayfish in sympatry (Souty-Grosset et al., 2006).

The condition indices indicated an improving condition in the noble crayfish with the hepatopancreas moisture declining in both groups dramatically (e.g., Jussila and Mannonen, 1997). The feeding obviously increases the index values with fatty Baltic herring diet giving lower moisture content. On the other hand, the condition index based on the muscle moisture reflects less dramatic response to treatments and there were no species specific differences between the treatments. The signal crayfish were originally in a better condition compared to the noble crayfish, so the changes were smaller but both species ended up being in similar physiological condition at the end the experiment. Groups fed using sweet corn diet were at the same level, while groups fed using Baltic herring diet had a minor difference and the noble crayfish showed indications of a poorer condition. The condition index data set should be used only to highlight the fact that the crayfish were consuming the feeds and that it had an impact on their physiology. Thus, the observed changes could be addressed to differences in feeding and feeds.

Based on the results, it is obvious that changes in the stable isotope profiles require longer time than the three months in this experiment and that the nutritional value of the experimental diets used in this study were most probably insufficient. The crayfish growth, and thus the effects of the nutrition in the tissue stable isotope content, requires crayfish to molt, which in total occurred only few times during the present study. The observed differences caused by different nutrition would have to be tested in an experiment that would last longer. Finally, there is an urgent need for laboratory scale controlled species-specific studies to address the repetitively detected gaps in our knowledge on tissue composition changes (Gannes et al., 1997; del Rio et al., 2009).

\section{ACKNOWLEDGEMENTS}

We would like to thank Hobo Kukkonen (UEF) for keeping an eye on the crayfish and the experiment. Research was done in RapuLatorio that has been supported by strategic funding of the UEF.

\section{REFERENCES}

Bodin N., Le Loc'h F. and Hily C., 2007. Effect of lipid removal on carbon and nitrogen stable isotope ratios in crustacean tissues. J. Exp. Mar. Biol. Ecol., 341, 168-175.

Carolan J.V., Mazumder D., Dimovski C., Diocares R. and Twining J., 2012. Biokinetics and discrimination factors for $\delta^{13} \mathrm{C}$ and $\delta^{15} \mathrm{~N}$ in the omnivorous freshwater crustacean, Cherax destructor. Mar. Freshwater Res., 63, 878-886.

Church D.C. and Pond W.G., 1982. Basic animal nutrition and feeding. John Wiley \& Sons, New York, USA.

Cortés-Jacinto E., Villarreal-Colmenares H., Civera-Cerecedo R. and Martinez-Córdova R., 2003. Effect of dietary protein level on growth and survival of juvenile freshwater crayfish Cherax quadricarinatus (Decapoda: Parastacidae). Aquacult. Nutr., 9, 207-213.

D'Abramo L.R., Conclin D.E. and Akiyama D.M., (eds.) 1997. Crustacean nutrition. Advances in world aquaculture. Volume 6. The World Aquaculture Society, Baton Rouge, USA.

Davis D.A. and Robinson E.H. 1986. Estimation of the dietary lipid requirement level of the white crayfish Procambarus acutus acutus. J. World Aquacult. Soc., 17, 37-43. 
del Rio C.M., Wolf N., Carleton S.A. and Gannes L.Z., 2009. Isotopic ecology ten years after a call for more laboratory experiments. Biol. Rev., 84, 91-111.

Ercoli F., Ruokonen T.J., Hämäläinen H. and Jones R.I. 2014. Does the introduced signal crayfish occupy an equivalent trophic niche to the lost native noble crayfish in boreal lakes? Biol. Inv., 16, 2025-2036.

Fantle M.S., Dittel A.I., Scwalm S.M., Epifanio C.E. and Fogel M.L., 1999. A food web analysis of the juvenile blue crab, Callinectes sapidus, using stable isotopes in whole animals and individual amino acids. Oecologia, 120, 416-426.

Fotedar R., 1999. Nutrition of Marron, Cherax tenuimanus (Smith), Under Different Culture ConditionsA Comparative Study. Doctoral Dissertation. Aquatic Science Research Unit, Curtin University, Perth, Western Australia.

Frazer T., Ross R., Quentin L. and Montoya J., 1997. Turnover of carbon and nitrogen during growth of larval krill, Euphausia superba Dana: a stable isotope approach. J. Exp. Mar. Biol. Ecol., 212, 259-275.

Gannes L.Z., O’Brien D.M. and Martinez Del Rio, C., 1997. Stable isotopes in animal ecology: assumptions, caveats, and a call for more laboratory experiments. Ecology, 78, 1271-1276.

Grey J., 2006. The use of stable istope analyses in freshwater ecology: current awareness. Pol. J. Ecol., $54,563-584$.

Gruber C., Kortet R., Vainikka A., Hyvärinen P., Rantala M.J., Pikkarainen A., Jussila J., Makkonen J., Kokko H. and Hirvonen H., 2014. Variation in resistance to the invasive crayfish plague and immune defence in the native noble crayfish. Annal. Zool. Fenn., 51, 371-389.

Gu H., Anderson A.J., Mather P.B. and Capra M.F. 1996. Effects of feeding level and starvation on growth and water and protein content in juvenile redclaw crayfish, Cherax quadricarinatus (von Martens). Mar. Freshwater Res., 47, 745-748.

Hazlet B., Rubenstein D. and Rittschoff D. 1975 Starvation, energy reserves and aggression in the crayfish Orconectes virilis (Hagen, 1870) (decapoda, Camridae). Crustaceana, 28, 11-16.

Hicks B.J., 1997. Food webs in forest and pasture streams in the Waikato region, New Zealand: A study based on analyses of stable isotopes of carbon and nitrogen, and fish gut contents. New Zeal. J. Mar. Fresh., 31, 651-664.

Hobson K.A. and Clark R.G., 1992. Assessing avian diets using stable isotopes I: Turnover of ${ }^{13} \mathrm{C}$ in tissues. The Condor, 94, 181-188.

Holdich, D.M. (2002) Biology of freshwater crayfish. Blackwell Science Ltd. Osney, Mead, Oxford, England.

Jackson M.C., Jones T., Milligan M., Sheath D., Taylor J., Ellis A., England J. and Grey J., 2014. Niche differentiation among invasive crayfish and their impacts on ecosystem structure and functioning. Freshw. Biol., 59, 1123-1135.

Jones P.L. and Obst J.H. 2000. Effects of starvation and subsequent refeeding on the size and nutrient content of the hepatopancreas of Cherax destructor (Decapoda: Parastacidae). J. Crust. Biol., 20, 431- 441

Jussila J., 1997. Physiological responses of Astacid and Parastacid crayfishes (Crustacea: Decapoda) to conditions of intensive culture. Doctoral Dissertation. Faculty of Natural and Environmental Sciences, University of Kuopio, Finland.

Jussila J. and Mannonen A., 1997. Marron (Cherax tenuimanus) and noble crayfish (Astacus astacus) hepatopancreas energy and its relationship to moisture content. Aquaculture, 149, 157-161.

Jussila J., Makkonen J. and Kokko H., 2011. Peracetic acid (PAA) treatment is an effective disinfectant against crayfish plague (Aphanomyces astaci) spores in aquaculture. Aquaculture, 320, 37-42.

Jussila J., Makkonen J., Vainikka A., Kortet R. and Kokko H., 2014. Crayfish plague dilemma: how to be a corteous killer. Boreal Environ. Res., 19, 235-244.

Kankaala P., Taipale S., Li L. and Jones R.I., 2010. Diets of crustacean zooplankton, inferred from stable carbon and nitrogen isotope analyses, in lakes with varying allochthonous dissolved organic carbon content. Aquat. Ecol., 44, 781-795.

Layman C.A., Arrington D.A., Montana C.G. and Post D.M., 2007. Can stable isotope ratios provide for community-wide measures of trophic structure? Ecology, 88, 42-48.

Layman C.A., Araujo M.S., Boucek R., Hammerschlag-Peyer C.M., Harrison E., Jud Z.R., Matich P., Rosenblatt A.E., Vaudo J.J., Yeager L.A., Post D.M. and Bearhop S., 2012. Applying stable isotopes to examine food-web structure: an overview of analytical tools. Biol. Rev., 87, 545-562. 
López-López S., Nolasco H., Villarreal-Colmenares H. and Civera-Cerecedo R., 2005. Digestive enzyme response to supplemental ingredients in practical diets for juvenile freshwater crayfish Cherax quadricarinatus. Aquacult. Nutr., 11, 79-85.

Makkonen J., 2013. The crayfish plague pathogen Aphanomyces astaci - genetic diversity and adaptation to the host species. Doctoral Dissertation. University of Eastern Finland, Faculty of Forestry and Natural Sciences, Kuopio, Finland.

Olsson K., Stenroth P., Nyström P. and Granéli W., 2009. Invasions and niche width: does niche width of an introduced crayfish differ from a native crayfish? Freshw. Biol., 54, 1731-1740.

Parkyn S.M., Collier K.J. and Hicks B.J., 2001. New Zealand stream crayfish: functional omnivores but trophic predators? Freshw. Biol., 46, 641-652.

Peterson B.J. and Fry B., 1987. Stable isotopes in ecosystem studies. Annu. Rev. Ecol. Syst., 18, 292-320.

Post D.M., 2002. Using stable isotopes to estimate trophic position: Models, methods, and assumptions. Ecology, 83, 703-718.

Roth B.M., Hein C.L. and Vander Zanden M.J. 2006. Using bioenergetics and stable isotopes to assess the trophic role of rusty crayfish (Orconectes rusticus) in lake littoral zones. Can. J. Fish. Aquat. Sci., 63, 335-344.

Rudnick D. and Resh V. 2005. Stable isotopes, mesocosms and gut content analysis demonstrate trophic differences in two invasive decapod crustacea. Freshw. Biol., 50, 1323-1336.

Ruokonen T.J., Kiljunen M., Karjalainen J. and Hämäläinen H., 2012. Invasive crayfish increase habitat connectivity in large boreal lakes. Knowl. Manag. Aquat. Ecosyst., 407, 08.

Sánchez-Paz A., García-Carreño F., Muhlia-Almazán A., Peregrino-Uriarte A.B., Hernández-López J. and Yepiz-Plascencia G., 2006. Usage of energy reserves in crustaceans during starvation: Status and future directions. Insect Biochem. Molec., 36, 241-249.

Saoud I.P., Garza De Yta A. and Ghanawi J., 2012. A review of nutritional biology and dietary requirements of red claw crayfish Cherax quadricarinatus (von Martens 1868). Aquacult. Nutr., 18, 349-368.

Schmidt K., Atkinson A., Stuebing D., McClelland J., Montoya J. and Voss M. 2003. Trophic relationships among southern ocean copepods and krill: some uses and limitations of a stable isotope approach. Limnol. Oceanography, 48, 277-289.

Souty-Grosset C., Holdich D.M., Noël P.Y., Reynolds J.D. and Haffner P. (eds.), 2006. Atlas of crayfish in Europe. Muséum national d'Historie naturelle, Paris, France.

Stenroth P., Holmqvist N., Nyström P., Berglund O., Larsson P. and Granéli W., 2006. Stable isotopes as an indicator of diet in omnivorous crayfish (Pacifastacus leniusculus): the influence of tissue, sample treatment, and season. Can. J. Fish. Aquat. Sci., 63, 821-831.

Suring E. and Wing S.R., 2009. Isotopic turnover rate and fractionation in multiple tissues of red rock lobster (Jasus edwardsii) and blue cod (Parapercis colias): Consequences for ecological studies. J. Exp. Mar. Biol. Ecol., 370, 56-63.

Syväranta J., Högmander P., Keskinen T., Karjalainen J. and Jones R.I., 2011. Altered energy flow pathways in a lake ecosystem following manipulation of fish community structure. Aquatic Sci., 73, 79-89.

Vainikka A., Rantala M.J., Niemelä P., Hirvonen H. and Kortet R., 2011. Boldness as a consistent personality trait in the noble crayfish, Astacus astacus. Acta Ethol., 14, 17-25.

Vander Zanden M.J., Casselman J.M. and Rasmussen J.B., 1999. Stable isotope evidence for the food web consequences of species invasions in lakes. Nature, 401, 464-467.

Vander Zanden M.J., Vadeboncoeur Y., Diebel M.W. and Jeppesen E., 2005. Primary consumer stable nitrogen isotopes as indicators of nutrient source. Envir. Sci. Tech., 39, 7509-7515.

Yokoyama H., Tamaki A., Harada K., Shimoda K., Koyama K. and Ishihi Y., 2005. Variability of diet-tissue isotopic fractionation in estuarine macrobenthos. Mar. Ecol. Prog. Ser., 296, 115-128.

Cite this article as: J. Jussila, T.J. Ruokonen, J. Syväranta, H. Kokko, A. Vainikka, J. Makkonen and R. Kortet, 2015. It takes time to see the menu from the body: an experiment on stable isotope composition in freshwater crayfishes. Knowl. Manag. Aquat. Ecosyst., 416, 25. 